\title{
Development and application of molecular biomarkers for characterizing Caribbean Yellow Band Disease in Orbicella faveolata
}

Michael Morgan, Kylia Goodner, James Ross, Angela Z Poole, Elizabeth Stepp, Christopher H Stuart, Cydney Wilbanks, Ernesto Weil

Molecular stress responses associated with coral diseases represent an under-studied area of cnidarian transcriptome investigations. Caribbean Yellow Band Disease (CYBD) is considered a disease of Symbiodinium within the tissues of the coral host Orbicella faveolata. There is a paucity of diagnostic tools to assist in the early detection and characterization of coral diseases. The validity of a diagnostic test is determined by its ability to distinguish host organisms that have the disease from those that do not. The ability to detect and identify disease-affected tissue before visible signs of the disease are evident would then be a useful diagnostic tool for monitoring and managing disease outbreaks. Representational Difference Analysis (RDA) was utilized to isolate differentially expressed genes in 0 . faveolata exhibiting CYBD. Preliminary screening of RDA products identified a small number of genes of interest (GOI) which included an early growth response factor and ubiquitin ligase from the coral host as well as cytochrome oxidase from the algal symbiont. To further characterize the specificity of response, quantitative real-time PCR (qPCR) was utilized to compare the expression profiles of these GOls within diseased tissues (visible lesions), tissues that precede visible lesions by $2-4 \mathrm{~cm}$ (transition area), and tissues from healthy-looking colonies with no signs of disease. Results show there are distinctive differences in the expression profiles of these three GOls within each tissue examined. Collectively, this small suite of GOls can provide a molecular "finger print" which is capable of differentiating between infected and uninfected colonies on reefs where CYBD is known to occur. 
1

2

3

4

5

6

7

8 Michael B. Morgan ${ }^{1}$, Kylia Goodner ${ }^{4}$, James Ross ${ }^{1}$, Angela Poole ${ }^{3}$, S. Elizabeth Stepp ${ }^{1}$, Chris

9 Stuart $^{5}$, Cydney D. Wilbanks ${ }^{1}$, Ernesto Weil ${ }^{2}$

21

22 Corresponding author and address:

23 Michael B. Morgan

24 Berry College

25 School of Mathematics and Natural Sciences

262277 Martha Berry Hwy

27 Mount Berry, GA 30149

28

29

30

31

${ }^{1}$ Department of Biology, Berry College, Mount Berry, GA 30149 USA

${ }^{2}$ Department of Marine Sciences, University of Puerto Rico, PO Box 3208, Lajas 00667, Puerto Rico

Present Address:

${ }^{3}$ Western Oregon University, Department of Biology, 345 N Monmouth Ave, Monmouth, OR 97361

${ }^{4}$ Yale University, Department of Genetics, Yale School of Medicine, PO Box 208005, New Haven, CT 06520-8005 USA

${ }^{5}$ Department of Molecular Medicine, Wake Forest School of Medicine, Winston-Salem, NC 27157 USA

Tel: 706-290-2148

Fax: 706-238-7855

email:mbmorgan@berry.edu 


\section{Abstract}

34 Molecular stress responses associated with coral diseases represent an under-studied area of cnidarian transcriptome investigations. Caribbean Yellow Band Disease (CYBD) is considered a disease of Symbiodinium within the tissues of the coral host Orbicella faveolata. There is a paucity of diagnostic tools to assist in the early detection and characterization of coral diseases. The validity of a diagnostic test is determined by its ability to distinguish host organisms that have the disease from those that do not. The ability to detect and identify disease-affected tissue before visible signs of the disease are evident would then be a useful diagnostic tool for monitoring and managing disease outbreaks. Representational Difference Analysis (RDA) was utilized to isolate differentially expressed genes in $O$. faveolata exhibiting CYBD. Preliminary screening of RDA products identified a small number of genes of interest (GOI) which included an early growth response factor and ubiquitin ligase from the coral host as well as cytochrome oxidase from the algal symbiont. To further characterize the specificity of response, quantitative real-time PCR (qPCR) was utilized to compare the expression profiles of these GOIs within

47 diseased tissues (visible lesions), tissues that precede visible lesions by $2-4 \mathrm{~cm}$ (transition area), 48 and tissues from healthy-looking colonies with no signs of disease. Results show there are 49 distinctive differences in the expression profiles of these three GOIs within each tissue examined. Collectively, this small suite of GOIs can provide a molecular "finger print" which is capable of differentiating between infected and uninfected colonies on reefs where CYBD is 52 known to occur. 


\section{Introduction:}

54 Worldwide, marine diseases are quickly spreading and creating a large ecological and economic

55 problem for global marine ecosystems (Harvell et al. 1999; Harvell et al. 2002; Burge et al.

56 2014). This problem is particularly important in coral reef ecosystems which have experienced

57 significant declines and phase shifts to algal dominated communities over the past 30 years.

58 Correlations are known to exists between increasing sea water temperatures, extensive and

59 intensive bleaching events, and the prevalence of disease outbreaks (Bruno et al. 2007; Hoegh-

60 Guldberg et al. 2007; Eakin et al. 2010; Ruiz-Moreno et al. 2012). Yellow Band Disease is a

61 disease affecting reef-building corals in the Caribbean and Indo-Pacific regions characterized by

62 a distinct yellow-to-white wide $(1-10 \mathrm{~cm})$ band or halo pattern separating healthy-looking tissue

63 and the algae-colonized, tissue-denuded skeleton (Figure 1) of infected colonies (Gil-Agudelo et

64 al. 2004; Weil 2004) and apparently by similar pathogens (Cervino et al. 2004a; Cervino et al.

65 2008) The Caribbean is a disease hot spot (Weil 2004) and Caribbean Yellow Band Disease

66 (CYBD) has caused significant mortalities in some of the major reef-building genera (Orbicella,

67 Montastraea) in the region since 1997 (Gil-Agudelo et al. 2004; Bruckner and Bruckner 2006;

68 Bruckner and Hill 2009; Weil, Cróquer and Urreiztieta 2009a; Weil and Rogers 2011). Although

69 no mode of transmission has been identified (Weil et al. 2008), it has been reported that CYBD

70 is caused by infection of the zooxanthellae with at least three Vibrio spp. causing degradation to

71 the symbiotic dinoflagellates of the genus Symbiodinium that reside within coral gastrodermal

72 cells (Cervino et al. 2004a; Cervino et al. 2004b; Cervino et al. 2008; Cunning et al. 2008). This

73 relationship forms the basis for the productivity and diversity of reef ecosystems and therefore

74 understanding how this disease influences the holobiont is extremely important in mitigating the

75 spread of this disease. 
77 Unlike other coral diseases, during infection with CYBD, Symbiodinium exhibit compromised 78 cellular integrity, loss of pigmentation and mortality. Algal cells remain inside the coral

79 endoderm, but as coral tissue loses pigmentation and transitions from yellow to pale yellow to 80 white, and is similar in appearance to bleached coral, most algal cells are dead (Cervino et al. 81 2004a; Cervino et al. 2008). The signs on the coral colonies are bands or halos of yellow-pale or 82 bleached tissues bordering the dead tissue areas on one side and fringing healthy-looking tissue 83 on the other (see Fig. 1) (Cervino et al. 2004a; Gil-Agudelo et al. 2004). Compounding the 84 effects of the disease, rising global water temperatures allows Vibrio to thrive (Harvell et al. 85 1999; Harvell et al. 2009). Comparisons between healthy and diseased corals at slightly elevated 86 water temperature found that while healthy corals survive, diseased corals had a $60-80 \%$ 87 mortality rate within a 96-hour period (Cervino et al. 2004a; Cervino et al. 2004b). The disease 88 has a systemic effect significantly reducing fecundity of infected colonies and therefore, fitness 89 of populations and species reducing the potential for natural recovery (Weil, Cróquer and 90 Urreiztieta 2009a). As worldwide water temperatures continue to rise, conditions favor new 91 infections and higher virulence of the Vibrio species that cause CYBD (Weil, Cróquer and 92 Urreiztieta 2009a). Therefore it is important to further clarify the transmission and progression 93 mechanisms in order to manage the disease and protect Caribbean coral ecosystems and the 94 ecological services they provide. The ability to detect and identify disease-affected tissue before 95 visible signs of the disease are evident can be a useful diagnostic tool for monitoring efforts 96 (Anderson, Armstrong and Weil 2013). 
98 Unfortunately, the development of diagnostic tools to predict and/or characterize disease

99 progression is limited (Pollock et al. 2011). Representational Difference Analysis (RDA) is a

100 form of subtractive hybridization that has been successfully used to detect stress responses at the

101 level of transcription in cnidarians (Morgan et al. 2012). Developing gene expression

102 biomarkers can be useful for monitoring health on coral reefs (Kenkel et al. 2014). The

103 application of RDA to coral diseases represent a small scale approach to isolating critical

104 transcriptional responses associated with healthy and/or diseased corals.

105

106 Sequencing of cnidarian genomes and transcriptomes has revealed a variety of potential pattern

107 recognition receptors (PRRs) that could be used to detect both harmful and beneficial microbes

108 and initiate signaling cascades including toll-like receptors, scavenger receptors, NOD-like

109 receptors, and lectins (Wood-Charlson et al. 2006; Miller et al. 2007; Shinzato et al. 2011;

110 Meyer and Weis 2012; Hamada et al. 2013; Poole and Weis 2014; Ocampo et al. 2015). In

111 addition, cnidarians have many components of vertebrate innate immune pathways that PRRs

112 may interact with to carry out cellular responses including the complement system, $\mathrm{Nf}-\mathrm{\kappa B}$

113 pathway, production of reactive oxygen species (ROS), antimicrobial peptides and the

114 prophenoloxidase pathway (Mydlarz et al. 2009; Shinzato et al. 2011; Vidal-Dupiol et al. 2011;

115 Wolenski et al. 2011; Ocampo et al. 2015). The involvement of these immune pathways in coral

116 diseases is still not well understood. Several transcriptomic studies have identified differential

117 expression of immune related transcripts between healthy and diseased states (Closek et al, 2014;

118 Libro et al, 2013; Vidol-Dupiol et al, 2014). One recent study on CYBD identified significant

119 changes in the host transcriptome which included downregulation of two antimicrobial peptides

120 and upregulation of two other immune genes in the diseased state as well as shifts in the 
121 microbial communities in tissues from healthy, diseased, and healthy border regions of the coral

122 (Closek et al. 2014). From these data it is clear that each coral disease generates a unique

123 response in the host and therefore characterization of differentially expressed genes between

124 different stages of disease progression is essential for the development of diagnostic tools to

125 predict and/or characterize the progression of a given disease. Characterizing specific responses

126 in both members of the holobiont transcriptome are important steps in order to better characterize

127 disease progression. The objective of this study was to identify responsive genes that can be

128 used to better characterize the development of CYBD in the important reef-building coral

129 Orbicella faveolata.

130

131 Materials and Methods

132 -Coral Collections

133 Coral samples were collected in Oct 2009 and Oct 2013 from La Parguera, Puerto Rico.

134 Specimens were collected under the General Collection Permit of the Department of Marine

135 Sciences, University of Puerto Rico, Mayaguez. Diseased and healthy colonies of Orbicella

136 faveolata were sampled from depth range of 9 to $12 \mathrm{~m}$. At the time of collection, all samples

137 were individually labeled, placed in plastic bags, and immediately transported back to the

138 laboratory where they were placed on a seawater table and immediately processed. Five colonies

139 with no visible evidence of disease were used as representative healthy tissue controls. Five

140 other colonies with visible CYBD lesions were sampled as representative of the diseased

141 condition. In addition, tissues were also sampled in the transition zone (Weil, Cróquer and

142 Urreiztieta 2009b), 2-4cm in front of the visible lesion border on the same five diseased coral

143 colonies. Diseased tissue (visible lesion) was identified and then separated from colony sample 
144 by chisel. Transition tissue was also taken from the same diseased colony. Transition tissues

145 were sampled approximately $2-4 \mathrm{~cm}$ in front of the advancing visually identified transition/lesion

146 border (see Fig. 1). Healthy colonies which had no visible signs of CYBD were also collected.

147 After each sample was isolated, approximately 2 to $3 \mathrm{~cm}^{2}$ of tissue was immersed in $5 \mathrm{mls}$ of

148 Trizol followed by immediate homogenization by vortexing. Total RNA was extracted

149 following Trizol protocol (Invitrogen, Carlsbad, CA, USA) with the additional use of $2 \mathrm{ml}$ 150 phase-lock gels (5'Prime, Gaithersburg, MD) to aid in the recovery of the aqueous phase. RNA

151 concentrations were estimated by absorbance readings at $260 \mathrm{~nm}$ (Biophotometer, Eppendorf,

152 Hauppauge, NY). The integrity of the total RNA was confirmed by electrophoresis of an aliquot

153 of each sample on a $1 \%$ formaldehyde agarose gel (Sambrook et al. 2001). Total RNA from

154 each sample was purified by DNase I digestion followed by phenol/ $\mathrm{CHCl}_{3}$ extraction (Message

155 Clean, GenHunter, Nashville, TN, USA). Messenger RNA (mRNA) was isolated (Oligotex,

156 Qiagen, Valencia, CA, USA) from $100 \mu \mathrm{g}$ of DNase I treated total RNA. Reverse transcription

157 of $1 \mu \mathrm{g}$ of mRNAs followed manufacturer's protocol (cDNA synthesis, Invitrogen, Carlsbad, CA,

158 USA) which also included the use of both oligo-dT and random hexamer primers. The RT-

159 reaction conditions were modified to 1 hour at $37^{\circ} \mathrm{C}$, followed by 1 minute at each temperature

160 between 42 and $50^{\circ} \mathrm{C}$ to maximize the number of full-length and partial transcripts copied

161 (Pastorian, Hawel and Byus 2000).

162

163

-Isolating RDA fragments

164 Hubank and Schatz (1999) provided the framework for the RDA protocol including RDA primer

165 sequences (Table 1), with modifications to the amount of starting material (Edman et al. 1997) 
166 and the elimination of mung bean nuclease (Pastorian, Hawel and Byus 2000). Double stranded

167 cDNA from each treatment was digested with DpnII (New England Biolabs, Ipswich, MA,

168 USA). Digested products were spin column purified to eliminate fragments smaller than $100 \mathrm{bp}$

169 in length (QIAquick PCR purification, Qiagen, Valencia, CA, USA). Primers R12 and R24 were

170 ligated onto the digested cDNAs at $15^{\circ} \mathrm{C}$ overnight in $60 \mu$ reactions. To generate sufficient

171 quantities of the required amplicons necessary for downstream protocols, replicate PCR reactions

172 were performed using $2.5 \mu \mathrm{l}$ of ligated cDNAs that were amplified for 20 cycles. Prior to

173 amplification, there was a 3 minute incubation at $72^{\circ} \mathrm{C}$. Subsequently, primer was added and

174 allowed to incubate for an additional 5 minutes. Once the entire 8 minute heating had elapsed,

175 Taq DNA polymerase was added and amplification proceeded for 20 cycles of 45 seconds at

$17695^{\circ} \mathrm{C}$ followed by 3 minutes at $72^{\circ} \mathrm{C}$ and then concluding for a final 10 minute extension at $72^{\circ} \mathrm{C}$.

178 Gel electrophoresis confirmed the size distribution within each amplicon. Twenty replicate PCR

179 reactions were pooled and then precipitated by isopropanol to concentrate. Each amplicon was

180 quantified by UV spectrophotometry and subsequently diluted with TE buffer to a final

181 concentration of $0.5 \mu \mathrm{g} / \mu \mathrm{l}$. Amplicons that were digested with DpnII (New England Biolabs,

182 Ipswich, MA, USA) to remove R24 primers became the cut-drivers which were used in

183 downstream reactions. Two rounds of hybridization were performed in this investigation. With

184 the assistance of J12 primer, the J24 primer was ligated onto cut-driver and used as the tester

185 amplicon in the first round of hybridization. Tester populations in the second round of

186 hybridizations used the N24/N12 primers. Ligation conditions were always the same throughout

187 the investigation even though the use of $\mathrm{J} 24 / \mathrm{J} 12$ or N24/N12 primers depended on the round of

188 hybridization. The ratio of tester/driver in round one was $1: 100$, whereas in round 2 it was 
189 1:800. The first round of hybridization combined $50 \mathrm{ng}$ of J24-ligated tester to $5 \mu \mathrm{g}$ of cut-

190 driver. The second round of subtraction/hybridization combined $6.25 \mathrm{ng}$ of N24-ligated

191 hybridization product from the first round of hybridization and $5 \mu \mathrm{g}$ of cut-driver. Each sample

192 population (healthy or diseased) was used as a tester in one series of hybridizations and as the

193 driver in the other series of hybridizations. After combining testers and drivers in the desired

194 ratio, pooled samples were extracted with Phenol/Chloroform/Isoamyl alcohol and then

195 precipitated in $30 \mu \mathrm{l}$ of $10 \mathrm{M}$ ammonium acetate and $250 \mu \mathrm{l}$ ethanol at $-70^{\circ} \mathrm{C}$ for one hour. After

196 centrifugation at $14,000 \mathrm{rpm}$ for $15 \mathrm{~min}$ at $4^{\circ} \mathrm{C}$, resulting pellets were washed twice in $70 \%$

197 ethanol and allowed to air dry. Each pellet was resuspended in $4 \mu 1$ EEx3 [30mM EPPS, pH 8.0

198 at $20^{\circ} \mathrm{C}, 3 \mathrm{mM}$ EDTA] buffer by pipetting repeatedly for 2 minutes then warmed to $37^{\circ} \mathrm{C}$ for 5

199 min, vortexed, and then briefly centrifuged. Samples were then overlayed with $35 \mu$ mineral oil

200 and then heated to $95^{\circ} \mathrm{C}$ for 5 minutes to denature. Afterwards they were allowed to cool to $67^{\circ} \mathrm{C}$

201 and $1 \mu 15 \mathrm{M} \mathrm{NaCl}$ was added directly into the DNA, and the samples were incubated overnight at

$20267^{\circ} \mathrm{C}$. After the overnight incubation, mineral oil was removed and samples were diluted in $95 \mu 1$

203 TE. Five microliters of a hybridization product were used in downstream PCR reactions. The

204 hybridization products were amplified by PCR beginning with a 3 minute incubation at $72^{\circ} \mathrm{C}$

205 followed by the addition of Taq DNA polymerase. After 5 additional minutes at $72^{\circ} \mathrm{C}$, primer

206 was added (either J24 or N24 primer depending on which round of hybridization had been

207 performed). Amplification conditions consisted of 45 seconds at $95^{\circ} \mathrm{C}$ followed by 3 minutes at

$20870^{\circ} \mathrm{C}(\mathrm{J} 24)$ or $72^{\circ} \mathrm{C}(\mathrm{N} 24)$ for a total of 27 cycles and then concluded with a 10 minute extension

209 at $72^{\circ} \mathrm{C}$. To eliminate the need of mung bean nuclease, a modified PCR reaction was employed

210 which involved taking a $10 \mu \mathrm{l}$ aliquot out of the PCR reaction after 7 cycles and placing it in a

211 new PCR reaction with all reagents and continuing for an additional 20 cycles (Pastorian, Hawel 
212 and Byus 2000). Amplified RDA products were cloned (TopoTA, Invitrogen, Carlsbad, CA,

213 USA) and then sequenced using M13 (forward and reverse) primers (Nevada Genomics Center,

214 University of Reno, NV, USA). Ninety-five sequences from CYBD infected tissues were cloned

215 and sequenced. Another 190 sequences were sequenced from RDA products representing

216 healthy tissues.

217

218 -Sequence Analysis

219 A contig assembly program (CAP3) (http://doua.prabi.fr/software/cap3) was used to determine

220 how many unique sequences were represented within the total number of cloned RDA products.

221 Sequences were compared against the nr and EST databases at NCBI (National Center for

222 Biotechnology Information) database (http://www.ncbi.nlm.nih.gov) using the BLASTX

223 algorithm with default parameters. CAP3 analysis indicated there were 9 contigs and 53

224 singletons.

225

226

-Virtual Northern Dot Blot screen

227 Two microliter aliquots of individually amplified RDA products were blotted onto replicate 228 positively charged nylon membranes. Amplicons were amplified by PCR using a DIG-labeled

229 nucleotide (Roche, Indianapolis, IN, USA). The presence/abundance of individual RDA

230 products was detected by chemiluminescence and quantified by densitometry (Morgan et al.

231 2012). One of the replicate membranes of RDA products was probed with DIG-labeled

232 amplicon from the healthy tissues, while the other replicate membrane was probed with DIG- 
233 labeled amplicon from the diseased tissues. DIG-labeled RDA products with differences in

234 signal intensities between the identical membranes were identified and selected as candidate

235 GOIs for subsequent qPCR analyses.

236

237

-Selection of GOIs and primer creation

238 Virtual Northerns (Franz, Bruchhaus and Roeder 1999) and BLAST analyses identified 14

239 potential genes of interest (GOIs) that were evaluated as candidates as a qPCR control gene or a

240 gene which is differentially expressed amongst the tissues (Table 2). Gene specific forward and

241 reverse primers were created for the GOIs using Primer3 (http://frodo.wi.mit.edu/primer3/)

242 (Table 3). Primer efficiency was initially screened by amplifying a target cDNA over a range of

$243 \mathrm{~T}_{\mathrm{m}}$ 's to determine optimal annealing (Mastercycler gradient, Eppendorf, Hauppauge, NY) and

244 then compared predicted amplicon size to observed amplicon size on a 2\% TBE agarose gel.

245 Five GOIs were chosen for further analyses (Table 4). Poly-A binding protein (PABP) was

246 chosen as the reference gene because it has previously demonstrated a consist pattern of

247 expression as a qPCR reference gene (Rodriguez-Lanetty et al. 2008). Four of the five genes

248 (EGR, Ubiquitin Ligase, Superoxide dismutase, and PABP) were representative of the coral host

249 while the fifth gene (Cytochrome Oxidase subunit 1) was representative of zooxanthellae.

250 Melt-curve analysis was performed to determine specificity of priming. Individual amplicons

251 were also extracted from agarose gels (Qiaquick gel extraction kit, Qiagen, Valencia, CA, USA)

252 and sequenced to confirm amplification of the intended target. 
256 Quantitative Real Time PCR (qPCR) assays were performed in four replicate $25 \mu \mathrm{L}$ reactions.

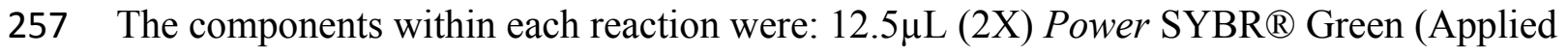

258 Biosystems, Carlsbad, CA), $2.5 \mu \mathrm{L}$ of forward and reverse primer (10 $\mu \mathrm{M}$ each), $2.5 \mu \mathrm{L}$ of 3 -fold

259 diluted cDNA from reverse-transcription reaction, $0.25 \mu \mathrm{L}$ Taq DNA polymerase (BioLabs,

260 Ipswich MA), and 4.75 $\mu$ L DI water. All qPCR reactions were performed on a StepOne ${ }^{\mathrm{TM}}$ Real

261 Time PCR machine (Applied Biosystems, Carlsbad, CA). Reaction conditions involved heating

262 at $95^{\circ} \mathrm{C}$ for 15 seconds, annealing for $54^{\circ} \mathrm{C}$ or $56^{\circ} \mathrm{C}$ for 20 seconds, and then elongating at $72^{\circ} \mathrm{C}$

263 for 20 seconds. All reactions were monitored by a melt curve analysis to ensure specific

264 amplification and absence of primer dimerization. Reactions were ramped from $60^{\circ} \mathrm{C}$ to $95^{\circ} \mathrm{C}$ at

265 a rate of $0.3^{\circ} \mathrm{C} \mathrm{s}^{-1}$.

266

267 -Expression Analysis

268 Replicate Cq values for each GOI were averaged to determine $\Delta \mathrm{Cq}$ and $\Delta \Delta \mathrm{Cq}$ for each sample

269 within a health condition. All qPCR $\Delta \mathrm{Cq}$ and $\Delta \Delta \mathrm{Cq}$ values are based on the consistent

270 expression of the PABP across all samples in this study. The $\Delta \Delta \mathrm{Cq}$ method was used to

271 determine the differences between targeted GOIs and a single reference gene (Bustin et al. 2009).

272 One-way ANOVA was used on the $\Delta \Delta \mathrm{Cq}$ data to identify significant differences in the

273 expression of an individual GOI within tissues representing different stages of the disease (ie,

274 diseased, transition, healthy). Similarities in variance were determined by Levene's Test of

275 Equality of Error Variances. If the variance between disease stages was similar, then the

276 Student-Neuman-Keuls (SNK) posthoc test was performed to determine which group(s) were 
277 significantly different from the rest. If variance between disease stages was different, then

278 Tamhane's T2 posthoc test was applied since One-way ANOVA is generally insensitive to

279 heterosedcasticity.

280

\section{Results}

282 Cytochrome oxidase had its highest average expression in transition zone tissues (Figure 2).

283 One-way ANOVA indicated that cytochrome oxidase expression was significantly lower

$284(\mathrm{P}<0.01)$ in healthy tissues compared to transition and diseased tissues (see Fig 2$)$. The highest

285 average expression for the EGR was in the diseased tissues and there were significant differences

286 in the levels of expression $(\mathrm{P}<0.01)$ of EGR in healthy tissues compared to transition and

287 diseased tissues (Figure 3). Ubiquitin ligase had its highest average expression in the diseased

288 tissues and there were significantly differences in expression $(\mathrm{P}<0.01)$ in diseased tissues

289 compared to transition and healthy tissues (Figure 4). Expression of superoxide dismutase-like

290 (SOD) was found to be similar across all samples, therefore no significant differences in

291 expression (data not shown).

292

293 Analysis was also performed on the collective expression of all three genes to determine whether

294 any significant differences existed between health conditions. One-way ANOVA of health

295 conditions also reaffirmed that there is a significant difference $(p<0.001)$ between the healthy

296 condition and the two different conditions associated with diseased colonies. 


\section{Discussion}

299 The purpose of this study was to characterize the expression profiles of a small suite of GOIs in 300 the Caribbean coral Orbicella faveolata exhibiting CYBD. This study does not identify the

301 pathogen or an associated virulence factor, but does identify transcriptional responses uniquely

302 associated with the coral host as well as the algal symbiont. Pollock et al. (2011) states the

303 validity of a diagnostic test is determined by its ability to distinguish host organisms that have

304 the disease from those that do not. This study demonstrates the application of a small suite of 305 genes that can differentiate between healthy colonies (no disease), diseased colonies (visible

306 lesions), and tissues that are nearby (transition area) and precede visible lesions on diseased

307 colonies. These three GOIs provide quantitative measurements of location-dependent changes in

308 their levels of transcription. Expression patterns of these GOIs expand our understanding of the

309 cellular processes associated with the development/progression of CYBD. This information also

310 advances our understanding of how the disease impacts tissues that precedes visible lesions. The

311 data herein also provides additional supporting evidence that CYBD is systemic as proposed by

312 Weil, Cróquer, and Urreiztieta (2009b), affecting tissues that do not show signs of the disease in

313 infected colonies.

315 Functional significance of GOI's

-Cytochrome oxidase:

317 Elevated expression of cytochrome oxidase in diseased and transition tissues reveals an increased

318 demand for energy. Diseased tissues have previously been characterized as having significantly

319 fewer Symbiodinium (Cervino et al. 2004a; Cervino et al. 2008), and yet another study indicates 
320 that zooxanthellae densities are not necessarily lower in diseased tissues (Mydlarz et al. 2009).

321 Concurrently, transition tissues visually appear asymptomatic (Weil, Cróquer and Urreiztieta

322 2009b; Anderson, Armstrong and Weil 2013; Closek et al. 2014). By comparison, healthy

323 colonies with normal zooxanthellae densities do not exhibit elevated expression of cytochrome

324 oxidase (see Fig 2). Zooxanthellae densities were not quantified in this study. Cytochrome

325 oxidase expression reveals that mitochondrial function in zooxanthellae is impacted by CYBD.

326 Growth involves higher energy demands and investments which can have significant impacts on

327 the corals ability to respond to infectious disease and other stressed conditions such as bleaching

328 (Pinzon et al. 2014). Mitochondria as well as chloroplasts generate ATP for biosynthetic

329 reactions in autotrophic organisms. Both organelles are metabolically linked through the $\mathrm{C}_{2}$

330 pathway (Bauwe, Hagemann and Fernie 2010). Little attention has been given to the interaction

331 of mitochondria and chloroplast in stressed Symbiodinium. As the balance between

332 photosynthesis and photorespiration fluctuates in favor of photorespiration in chloroplasts, 333 photorespiration facilitates energy production in mitochondria (Tcherkez et al. 2008; Bauwe,

334 Hagemann and Fernie 2010). In CYBD tissues, chloroplasts are intact but grana and thylakoid 335 membranes appear disorganized (Cervino et al. 2004a). In addition, there is evidence that 336 photosynthetic pigments exhibit changes in spectral features within CYBD tissues (Anderson,

337 Armstrong and Weil 2013). Such changes are consistent with diminished light-capturing 338 capabilities of the photosynthetic machinery which would tilt the balance of

339 photosynthesis/photorespiration in favor of photorespiration. Up-regulation of cytochrome

340 oxidase in zooxanthellae from colonies exhibiting CYBD provides new molecular information

341 that is consistent the conclusions of Cervino et al. (2004a; 2008) that CYBD is a disease of

342 Symbiodinium. The elevated expression of cytochrome oxidase offers molecular evidence that 
343 zooxanthellae are exhibiting increased demands for energy. This zooxanthellae response for

344 increased energy production is distinctively different from the lack of investment in energy

345 production by the coral host as identified by Closek et al. (2014). The cytochrome oxidase

346 coupled with findings from Closek et al. (2014) reaffirms the conclusions of Pinzon et al. (2014)

347 that energy demands are intimately linked to holobiont's ability to responds to stressed

348 conditions. Quantifying expression of an algal gene (i.e. cytochrome oxidase) relative to PABP

349 expression of the coral host is a valid comparison because both genes are representative of the

350 transcriptional activity occurring in the holobiont at the time of tissue sampling.

351

352 -Early growth response:

353 Preliminary BLASTX results suggest that RDA product H1D1-64 is an early growth response

354 (EGR) which is known as a transcription factor (Barshis et al. 2013). This gene is known to be 355 associated with the initiation of immune responses (McMahon and Monroe 1996), mitogenesis

356 and cell growth (Sukhatme 1990), and tumor suppression (Huang et al. 1997). Corals are known

357 to have a complex repertoire of immune responses for how corals respond to a pathogen

358 (Sutherland, Porter and Torres 2004; Miller et al. 2007; Schwarz et al. 2008; Kvennefors et al.

359 2010; Shinzato et al. 2011; Poole and Weis 2014). Coral immune mechanisms include coral

360 wound healing, hemocytosis, phagocytosis, encapsulation, and basic immunological memory to

361 fight off pathogens (Sutherland, Porter and Torres 2004; Palmer and Traylor-Knowles 2012).

362 EGR has also previously demonstrated significant expression in corals responding to heat stress

363 (Barshis et al. 2013) which is a well-recognized stressor that can induce bleaching. There is a

364 growing body of evidence of linkages between bleaching and immune responses in cnidarians 
365 (Weis 2008; Kvennefors et al. 2010; Detournay et al. 2012; Pinzon et al. 2014; Pratte and

366 Richardson 2014). Elevated EGR expression in the transition tissues (see Fig 3) may represent

367 an important signal associated with a preliminary stage of infection in nearby tissues, but further

368 studies will need to be conducted to clarify the role of this protein in the progression of CYBD. -Ubiquitin ligase

371 Ubiquitin ligase in this study is representative of RING-type E3 ligases. Ubiquitination directs

372 many cellular functions including protein degradation (Komander and Rape 2012) and regulating

373 a variety of cellular processes including vesicle trafficking (Hsu et al. 2014), cell cycle control

374 (Skaar, Pagan and Pagano 2013), and immune responses (Jiang and Chen 2012). Results herein

375 reveal ubiquitin ligase is initially up-regulated in transition tissues, but peaks with highest

376 expression in visible lesion tissues (see Fig. 4). Elevated expression of ubiquitin ligase in

377 diseased tissues suggests this profile is representative of a later stage in the development of the

378 disease. Elevated expression of ubiquitin ligase in diseased tissues is particularly interesting for

379 a couple of reasons. Microbes are known to highjack host ubiquitin pathways in order to

380 manipulate host signaling to facilitate bacterial infection and proliferation (Zhou and Zhu 2015),

381 and Closek et al. (2014) identified CYBD diseased tissues having 2-3 times greater bacterial

382 diversity compared to healthy tissues while the transition tissues actually had the highest species

383 richness. Ubiquitination is also known to be associated with lysosomal degradation of plasma

384 membrane proteins (Komander and Rape 2012), therefore the expression profile of ubiquitin

385 ligase in this study is also consistent with elevated expression of lysosomal-like enzymes and 386 anti-microbial responses identified by Mydlarz et al. (2009). Ubiquitin ligase expression in this 
387 study may represent the nexus between the microbial diversity identified by Closek et al. (2014)

388 and the anti-microbial responses identified by Mydlarz et al. (2009).

389

390

Expression profiles enhance findings of previous CYBD studies

391 Results from this study show that transition tissue 2-4 cm away from a visible lesion exhibits a

392 different expression profile compared to visible lesion tissues (see Figs 2-4). These results

393 reaffirm conclusions of previous studies (Mydlarz et al. 2009; Weil, Cróquer and Urreiztieta

394 2009b; Anderson, Armstrong and Weil 2013; Closek et al. 2014) that characteristic differences

395 exists between healthy and diseased colonies, as well as differences between diseased tissues and 396 asymptomatic tissues that precede visible lesions on diseased colonies.

397

398 Results in this study coupled with Closek et al. (2014) findings that microbial diversity was

399 highest in tissues the precede visible lesions raise the intriguing possibility that pathogen(s)

400 responsible for CYBD may reside within the microbial community of the transition tissues. If

401 the etiological agent for inducing CYBD actually resides in the microbial community of the

402 transition tissues, then disease progression through a colony may actually follow a pattern similar

403 to secondary succession observed in terrestrial communities after a disturbance such as a fire.

404 The visible demarcation between transition tissues and lesion tissues corresponds to "fire line" of

405 the disturbance. Consequently, lesion tissues behind the "fire line" are committed to subsequent

406 degradation. Therefore the Symbiodinium response in transition tissues represents a potential

407 sentinel of the approaching disturbance. 
409 Mydlarz et al. (2009) investigated the anti-oxidant responses of prophenoloxidase (PPO) and 410 peroxidase (POX) in CYBD tissues. Without the presence of significant ROS, down-regulation 411 of PPO and POX in CYBD tissues would be expected when amounts of reactive oxygen species 412 (ROS) generated is minimal. As previously identified, there was no significant up-regulated 413 expression of SOD in coral host tissues (data not shown) which is congruent with the down414 regulation of the antioxidant enzymes quantified by Mydlarz et al. (2009) and the absence of 415 SOD expression identified by Closek et al. (2014). Concurrently, the mitochondrial response of 416 elevated cytochrome oxidase further suggests a potential link between the absence of detectable 417 ROS and the metabolic process of photorespiration which integrates the functions of 418 mitochondria, chloroplasts, and peroxisomes through the photorespiratory $\mathrm{C}_{2}$ cycle (Bauwe, 419 Hagemann and Fernie 2010; Voss et al. 2013).

420

\section{Conclusions}

422 This study has characterized CYBD in the Caribbean coral Orbicella faveolata by quantifying

423 the expression patterns of three GOIs (cytochrome oxidase, EGR, and ubiquitin ligase).

424 Individually, expression of these GOIs reveal altered physiology that can be attributed to a wide

425 variety of stressed conditions. Collectively, these GOIs represent a potential diagnostic tool

426 capable of differentiating between healthy and diseased colonies as well as between two different

427 stages of CYBD within a diseased colony. The expression profiles of these three GOIs in

428 transition tissues compared to healthy and diseased tissues suggest the initial development of this 429 disease begins before visible lesions are evident. Quantification of a small suite of genes by 
430 qPCR from within a complex pool of animal and algal transcripts reaffirms the specificity of the

431 technique previously demonstrated by Seneca et al. (2010) and achieves the goal of sensitivity

432 and specificity of a molecular diagnostic tool to understand the cellular events associated with

433 disease pathogenesis as outlined by Pollock et al. (2011). The collective expression of these

434 three GOIs produces expression profiles that are uniquely different between transition, diseased,

435 and healthy tissues. Collectively, expression of these GOIs provides greater resolution for

436 differences that exist between tissues on both sides of the well-defined reference point of the

437 transition/lesion border of CYBD colonies. Biomarkers are most effective when they can detect

438 stress signals that vary in intensity (Tyler and Gretchen 2012; Kenkel et al. 2014). Signal

439 intensity increases (healthy $<$ transition $<$ diseased) for EGR and ubiquitin ligase, but signal

440 intensity peaks (healthy $<$ transition $>$ diseased) for cytochrome oxidase. While the expression

441 profile of each GOI is different from the other GOIs, it is their collective expression can discern

442 differences that the physiological status of healthy, transitional, and diseased tissues. The

443 diagnostic power of these GOIs remain tentative without more extensive sampling to account for

444 genotypic variation of individual colonies and the distance tissues are sampled from the visible

445 demarcation of a lesion. Future transect sampling can provide greater resolution about the

446 distance from a visible lesion that these signals can be detected which may help to further

447 characterize the size of a "virulence wave" that precedes visible lesions. The data in this study

448 expands the current understanding of the molecular responses associated with CYBD infections

449 and the results identify significant responses associated with different members of the holobiont.

450 Lastly, this suite of GOIs offers an assessment tool that may provide greater resolution to the

451 spatial distribution of colonies susceptible to infections of CYBD on a reef. Studies such as

452 Soto-Santiago and Weil (2012) which quantified the spatial distribution of CYBD at various reef 
453 locations may find greater resolution in the distribution patterns of CYBD by incorporating these

454 GOIs to screen for colonies in early stages of this disease that precede visible lesions. Detection

455 of colonies in the earliest stages of CYBD may also help to spatially identify colonies at greatest

456 risk of developing CYBD.

457

458 As our understanding of how environmental and anthropogenic stressors influence the

459 transmission of CYBD continues to expand, there will be increasing demands for rapid assays

460 capable providing resource managers with relevant field monitoring information to make timely

461 decisions. Future studies may also use these GOIs to assist in further characterizing other

462 stressed conditions such as bleaching. The methodologies employed herein can be applied to

463 studies of other coral diseases as well. Each coral disease with a unique etiology will have its

464 own distinctive transcriptional "finger print" representing critical metabolic pathways that are

465 impacted on a specific temporal/spatial scale. While whole transcriptome analysis maybe ideal,

466 many labs are not financially equipped to employ such analyses. RDA represents an inexpensive

467 alternative to transcriptome-wide assays used to identify critical components of a specific

468 stressed condition. Both RDA and/or transcriptome analysis can be used to identify GOIs of

469 critical biochemical pathways for CYBD or any other coral disease. Once candidate GOIs are

470 identified, they can be coupled with qPCR and used to generate a transcriptional profile uniquely

471 associated with a particular coral disease. Such assays are capable of providing valuable

472 transcriptional information within hours of tissue sampling.

\section{Acknowledgements}


475 We wish to acknowledge the laboratory assistance of Peggy Molyneux and Preston Neely. 
476

477

478

479

480

481

482

483

484

485

486

487

488

489

490

491

492

493

494

495

496

497

498

499

500

501

502

503

504

505

506

507

508

509

510

511

512

513

514

515

516

517

518

519

520

521

\section{References}

Anderson, D. A., Armstrong, R. A., Weil, E. (2013). Hyperspectral Sensing of Disease Stress in the Caribbean Reef-Building Coral, Orbicella faveolata - Perspectives for the Field of Coral Disease Monitoring. PloS one 8(12). DOI: 10.1371/journal.pone.0081478.

Barshis, D. J., Ladner, J. T., Oliver, T. A., Seneca, F. O., Traylor-Knowles, N., Palumbi, S. R. (2013). Genomic basis for coral resilience to climate change. Proceedings of the National Academy of Sciences of the United States of America 110(4): 1387-1392. DOI: 10.1073/pnas. 1210224110.

Bauwe, H., Hagemann, M., Fernie, A. R. (2010). Photorespiration: players, partners and origin. Trends Plant Science 15(6): 330-336. DOI: 10.1016/j.tplants.2010.03.006.

Bruckner, A. W., Bruckner, R. J. (2006). Consequences of yellow band disease (YBD) on Montastraea annularis (species complex) populations on remote reefs off Mona Island, Puerto Rico. Diseases of Aquatic Organisms 69(1): 67-73. DOI: 10.3354/dao069067.

Bruckner, A. W., Hill, R. L. (2009). Ten years of change to coral communities off Mona and Desecheo Islands, Puerto Rico, from disease and bleaching. Diseases of Aquatic Organisms 87(1-2): 19-31. DOI: 10.3354/dao02120.

Bruno, J. F., Selig, E. R., Casey, K. S., Page, C. A., Willis, B. L., Harvell, C. D., Sweatman, H., Melendy, A. M. (2007). Thermal stress and coral cover as drivers of coral disease outbreaks. PLoS Biology 5(6): e124. DOI: 10.1371/journal.pbio.0050124.

Burge, C. A., Mark Eakin, C., Friedman, C. S., Froelich, B., Hershberger, P. K., Hofmann, E. E., Petes, L. E., Prager, K. C., Weil, E., Willis, B. L., Ford, S. E., Harvell, C. D. (2014). Climate change influences on marine infectious diseases: implications for management and society. Ann Rev Mar Sci 6: 249-277. DOI: 10.1146/annurev-marine-010213135029.

Bustin, S. A., Benes, V., Garson, J. A., Hellemans, J., Huggett, J., Kubista, M., Mueller, R., Nolan, T., Pfaffl, M. W., Shipley, G. L., Vandesompele, J., Wittwer, C. T. (2009). The MIQE guidelines: minimum information for publication of quantitative real-time PCR experiments. Clinical Chemistry 55(4): 611-622. DOI: 10.1373/clinchem.2008.112797.

Cervino, J. M., Hayes, R., Goreau, T. J., Smith, G. W. (2004a). Zooxanthellae regulation in yellow blotch/band and other coral diseases contrasted with temperature related bleaching: In situ destruction vs expulsion. Symbiosis 37(1-3): 63-85.

Cervino, J. M., Hayes, R. L., Polson, S. W., Polson, S. C., Goreau, T. J., Martinez, R. J., Smith, G. W. (2004b). Relationship of Vibrio species infection and elevated temperatures to yellow blotch/band disease in Caribbean corals. Applied And Environmental Microbiology 70(11): 6855-6864. DOI: 10.1128/aem.70.11.6855-6864.2004.

Cervino, J. M., Thompson, F. L., Gomez-Gil, B., Lorence, E. A., Goreau, T. J., Hayes, R. L., Winiarski-Cervino, K. B., Smith, G. W., Hughen, K., Bartels, E. (2008). The Vibrio core group induces yellow band disease in Caribbean and Indo-Pacific reef-building corals. Journal of Applied Microbiology 105(5): 1658-1671. DOI: 10.1111/j.13652672.2008.03871.x.

Closek, C. J., Sunagawa, S., DeSalvo, M. K., Piceno, Y. M., DeSantis, T. Z., Brodie, E. L., Weber, M. X., Voolstra, C. R., Andersen, G. L., Medina, M. (2014). Coral transcriptome and bacterial community profiles reveal distinct Yellow Band Disease states in Orbicella faveolata. The ISME Journal. DOI: 10.1038/ismej.2014.85.

Cunning, J. R., Thurmond, J. B., Smith, G. W., Weil, E., Ritchie, K. B. (2008). A survey of vibrios associated with healthy and Yellow Band Diseased Montastraea faveolata. . 
522

523

524

525

526

527

528

529

530

531

532

533

534

535

536

537

538

539

540

541

542

543

544

545

546

547

548

549

550

551

552

553

554

555

556

557

558

559

560

561

562

563

564

565

566

Proceedings of the 11th International Coral Reef Symposium, Ft Lauderdale, USA. 206210.

Detournay, O., Schnitzler, C. E., Poole, A., Weis, V. M. (2012). Regulation of cnidariandinoflagellate mutualisms: Evidence that activation of a host TGF beta innate immune pathway promotes tolerance of the symbiont. Developmental and comparative immunology 38(4): 525-537. DOI: 10.1016/j.dci.2012.08.008.

Eakin, C. M., Morgan, J. A., Heron, S. F., Smith, T. B., Liu, G., Alvarez-Filip, L., Baca, B., Bartels, E., Bastidas, C., Bouchon, C., Brandt, M., Bruckner, A. W., Bunkley-Williams, L., Cameron, A., Causey, B. D., Chiappone, M., Christensen, T. R., Crabbe, M. J., Day, O., de la Guardia, E., Diaz-Pulido, G., DiResta, D., Gil-Agudelo, D. L., Gilliam, D. S., Ginsburg, R. N., Gore, S., Guzman, H. M., Hendee, J. C., Hernandez-Delgado, E. A., Husain, E., Jeffrey, C. F., Jones, R. J., Jordan-Dahlgren, E., Kaufman, L. S., Kline, D. I., Kramer, P. A., Lang, J. C., Lirman, D., Mallela, J., Manfrino, C., Marechal, J. P., Marks, K., Mihaly, J., Miller, W. J., Mueller, E. M., Muller, E. M., Orozco Toro, C. A., Oxenford, H. A., Ponce-Taylor, D., Quinn, N., Ritchie, K. B., Rodriguez, S., Ramirez, A. R., Romano, S., Samhouri, J. F., Sanchez, J. A., Schmahl, G. P., Shank, B. V., Skirving, W. J., Steiner, S. C., Villamizar, E., Walsh, S. M., Walter, C., Weil, E., Williams, E. H., Roberson, K. W., Yusuf, Y. (2010). Caribbean corals in crisis: record thermal stress, bleaching, and mortality in 2005. PloS one 5(11): e13969. DOI:

10.1371/journal.pone.0013969.

Edman, C. F., Prigent, S. A., Schipper, A., Feramisco, J. R. (1997). Identification of ErbB3stimulated genes using modified representational difference analysis. Biochemistry Journal 323: 113-118.

Franz, O., Bruchhaus, I., Roeder, T. (1999). Verification of differential gene transcription using virtual northern blotting. Nucleic Acids Research 27(11): e3.

Gil-Agudelo, D. L., Smith, G. W., Garzon-Ferreira, J., Weil, E., Petersen, D. (2004). Dark spots disease and yellow band disease, two poorly known coral diseases with high incidence in Caribbean reefs. In Coral Health and Disease. Rosenberg E. and Loya Y., ed, 337-349.

Hamada, M., Shoguchi, E., Shinzato, C., Kawashima, T., Miller, D. J., Satoh, N. (2013). The Complex NOD-Like Receptor Repertoire of the Coral Acropora digitifera Includes Novel Domain Combinations. Molecular Biology and Evolution 30(1): 167-176. DOI: 10.1093/molbev/mss213.

Harvell, C. D., Kim, K., Burkholder, J. M., Colwell, R. R., Epstein, P. R., Grimes, D. J., Hofmann, E. E., Lipp, E. K., Osterhaus, A. D. M. E., Overstreet, R. M., Porter, J. W., Smith, G. W., Vasta, G. R. (1999). Emerging Marine Diseases-Climate Links and Anthropogenic Factors. Science 285: 1505-1510.

Harvell, C. D., Mitchell, C. E., Ward, J. R., Altizer, S., Dobson, A. P., Ostfeld, R. S., Samuel, M. D. (2002). Climate warming and disease risks for terrestrial and marine biota. Science 296(5576): 2158-2162. DOI: 10.1126/science.1063699.

Harvell, D., Altizer, S., Cattadori, I. M., Harrington, L., Weil, E. (2009). Climate change and wildlife diseases: When does the host matter the most? Ecology 90(4): 912-920. DOI: 10.1890/08-0616.1.

Hoegh-Guldberg, O., Mumby, P. J., Hooten, A. J., Steneck, R. S., Greenfield, P., Gomez, E., Harvell, C. D., Sale, P. F., Edwards, A. J., Caldeira, K., Knowlton, N., Eakin, C. M., Iglesias-Prieto, R., Muthiga, N., Bradbury, R. H., Dubi, A., Hatziolos, M. E. (2007). 
567

568

569

570

571

572

573

574

575

576

577

578

579

580

581

582

583

584

585

586

587

588

589

590

591

592

593

594

595

596

597

598

599

600

601

602

603

604

605

606

607

608

609

610
Coral reefs under rapid climate change and ocean acidification. Science 318(5857): 17371742. DOI: $10.1126 /$ science. 1152509.

Hsu, F. S., Luo, X., Qiu, J. Z., Teng, Y. B., Jin, J. P., Smolka, M. B., Luo, Z. Q., Mao, Y. X. (2014). The Legionella effector SidC defines a unique family of ubiquitin ligases important for bacterial phagosomal remodeling. Proceedings of the National Academy of Sciences of the United States of America 111(29): 10538-10543. DOI: 10.1073/pnas.1402605111.

Huang, R. P., Fan, Y., deBelle, I., Niemeyer, C., Gottardis, M. M., Mercola, D., Adamson, E. D. (1997). Decreased EGR-1 expression in human, mouse and rat mammary cells and tissues correlates with tumor formation. International Journal of Cancer 72(1): 102-109. DOI: 10.1002/(sici)1097-0215(19970703)72:1<102::aid-ijc15>3.0.co;2-1.

Hubank, M., Schatz, D. G. (1999). cDNA Representational difference analysis: A sensitive and flexible method for identification of differentially expressed genes. In Methods in Enzymology; cDNA preparation and characterization. Weissman S. M., ed, Academic Press, San Diego, California, USA, 325-349.

Jiang, X. M., Chen, Z. J. J. (2012). The role of ubiquitylation in immune defence and pathogen evasion. Nature Reviews Immunology 12(1): 35-48. DOI: 10.1038/nri3111.

Kenkel, C. D., Sheridan, C., Leal, M. C., Bhagooli, R., Castillo, K. D., Kurata, N., McGinty, E., Goulet, T. L., Matz, M. V. (2014). Diagnostic gene expression biomarkers of coral thermal stress. Molecular Ecology Resources 14(4): 667-678. DOI: 10.1111/17550998.12218.

Komander, D., Rape, M. (2012). The Ubiquitin Code. Annual Review of Biochemistry 81: 203229. DOI: 10.1146/annurev-biochem-060310-170328.

Kvennefors, E. C. E., Leggat, W., Kerr, C. C., Ainsworth, T. D., Hoegh-Guldberg, O., Barnes, A. C. (2010). Analysis of evolutionarily conserved innate immune components in coral links immunity and symbiosis. Developmental and comparative immunology 34(11): 12191229. DOI: 10.1016/j.dci.2010.06.016.

McMahon, S. B., Monroe, J. G. (1996). The role of early growth response gene 1 (egr-1) in regulation of the immune response. Journal of Leukocyte Biology 60(2): 159-166.

Meyer, E., Weis, V. M. (2012). Study of Cnidarian-Algal Symbiosis in the "Omics" Age. Biological Bulletin (Woods Hole) 223(1): 44-65.

Miller, D. J., Hemmrich, G., Ball, E. E., Hayward, D. C., Khalturin, K., Funayama, N., Agata, K., Bosch, T. C. (2007). The innate immune repertoire in cnidaria--ancestral complexity and stochastic gene loss. Genome Biology 8(4): R59. DOI: 10.1186/gb-2007-8-4-r59.

Morgan, M. B., Parker, C. C., Robinson, J. W., Pierce, E. M. (2012). Using Representational Difference Analysis to detect changes in transcript expression of Aiptasia genes after laboratory exposure to lindane. Aquatic Toxicology 110: 66-73. DOI: 10.1016/j.aquatox.2012.01.001.

Mydlarz, L. D., Couch, C. S., Weil, E., Smith, G., Harvell, C. D. (2009). Immune defenses of healthy, bleached and diseased Montastraea faveolata during a natural bleaching event. Diseases of Aquatic Organisms 87(1-2): 67-78. DOI: 10.3354/dao02088.

Ocampo, I., Zárate-Potes, A., Pizarro, V., Rojas, C., Vera, N., Cadavid, L. (2015). The immunotranscriptome of the Caribbean reef-building coral Pseudodiploria strigosa. Immunogenetics: 1-16. DOI: 10.1007/s00251-015-0854-1. 
611 Palmer, C. V., Traylor-Knowles, N. (2012). Towards an integrated network of coral immune

612

613

614

615

616

617

618

619

620

621

622

623

624

625

626

627

628

629

630

631

632

633

634

635

636

637

638

639

640

641

642

643

644

645

646

647

648

649

650

651

652

653

654

655

656 mechanisms. Proceedings of the Royal Society B-Biological Sciences 279(1745): 41064114. DOI: $10.1098 / \mathrm{rspb} .2012 .1477$.

Pastorian, K., Hawel, L., Byus, C. V. (2000). Optimization of cDNA representational difference analysis for the identification of differentially expressed mRNAs. Analytical Biochemistry 283(1): 89-98.

Pinzon, C. J. H., Dornberger, L., Beach-Letendre, J., Weil, E., Mydlarz, L. D. (2014). The link between immunity and life history traits in scleractinian corals. PeerJ 2. DOI: 10.7717/peerj.628.

Pollock, F. J., Morris, P. J., Willis, B. L., Bourne, D. G. (2011). The Urgent Need for Robust Coral Disease Diagnostics. Plos Pathogens 7(10): e1002183. DOI: 10.1371/journal.ppat.1002183.

Poole, A. Z., Weis, V. M. (2014). TIR-domain-containing protein repertoire of nine anthozoan species reveals coral-specific expansions and uncharacterized proteins. Developmental and comparative immunology 46(2): 480-488. DOI: 10.1016/j.dci.2014.06.002.

Pratte, Z. A., Richardson, L. L. (2014). Impacts of temperature increase and acidification on thickness of the surface mucopolysaccharide layer of the Caribbean coral Diploria spp. Coral Reefs 33(2): 487-496. DOI: 10.1007/s00338-013-1115-0.

Ruiz-Moreno, D., Willis, B. L., Page, A. C., Weil, E., Croquer, A., Vargas-Angel, B., JordanGarza, A. G., Jordan-Dahlgren, E., Raymundo, L., Harvell, C. D. (2012). Global coral disease prevalence associated with sea temperature anomalies and local factors. Diseases of Aquatic Organisms 100(3): 249-261. DOI: 10.3354/dao02488.

Schwarz, J. A., Brokstein, P. B., Voolstra, C., Terry, A. Y., Manohar, C. F., Miller, D. J., Szmant, A. M., Coffroth, M. A., Medina, M. (2008). Coral life history and symbiosis: functional genomic resources for two reef building Caribbean corals, Acropora palmata and Montastraea faveolata. BMC Genomics 9: 97. DOI: 10.1186/1471-2164-9-97.

Seneca, F. O., Foret, S., Ball, E. E., Smith-Keune, C., Miller, D. J., van Oppen, M. J. H. (2010). Patterns of Gene Expression in a Scleractinian Coral Undergoing Natural Bleaching. Marine Biotechnology 12(5): 594-604. DOI: 10.1007/s10126-009-9247-5.

Shinzato, C., Shoguchi, E., Kawashima, T., Hamada, M., Hisata, K., Tanaka, M., Fujie, M., Fujiwara, M., Koyanagi, R., Ikuta, T., Fujiyama, A., Miller, D. J., Satoh, N. (2011). Using the Acropora digitifera genome to understand coral responses to environmental change. Nature (London) 476(7360): 320. DOI: 10.1038/nature10249.

Skaar, J. R., Pagan, J. K., Pagano, M. (2013). Mechanisms and function of substrate recruitment by F-box proteins. Nature Reviews Molecular Cell Biology 14(6): 369-381. DOI: $10.1038 / \mathrm{nrm} 3582$.

Soto-Santiago, F. J., Weil, E. (2012). Incidence and Spatial Distribution of Caribbean Yellow Band Disease in La Parguera, Puerto Rico. Journal of Marine Biology 2012. DOI: $10.1155 / 2012 / 510962$.

Sukhatme, V. P. (1990). Early transcriptional events in cell growth - The EGR family. Journal of the American Society of Nephrology 1(6): 859-866.

Sutherland, K. P., Porter, J. W., Torres, C. (2004). Disease and immunity in Caribbean and IndoPacific zooxanthellate corals. Marine Ecology Progress Series 266: 273-302. DOI: 10.3354/meps266273.

Tcherkez, G., Bligny, R., Gout, E., Mahe, A., Hodges, M., Cornic, G. (2008). Respiratory metabolism of illuminated leaves depends on $\mathrm{CO} 2$ and $\mathrm{O} 2$ conditions. Proceedings of the 
657

658

659

660

661

662

663

664

665

666

667

668

669

670

671

672

673

674

675

676

677

678

679

680

681

682

683

684

685

686

687

688

689

690

691

692

693

694

695

696

697

698
National Academy of Sciences of the United States of America 105(2): 797-802. DOI: 10.1073/pnas.0708947105.

Tyler, G. E., Gretchen, E. H. (2012). Defining the limits of physiological plasticity: how gene expression can assess and predict the consequences of ocean change. Philosophical transactions of the Royal Society of London. Series B, Biological sciences 367(1596): 1733-1745. DOI: 10.1098/rstb.2012.0019.

Vidal-Dupiol, J., Ladriere, O., Destoumieux-Garzon, D., Sautiere, P. E., Meistertzheim, A. L., Tambutte, E., Tambutte, S., Duval, D., Foure, L., Adjeroud, M., Mitta, G. (2011). Innate immune responses of a scleractinian coral to vibriosis. Journal of Biological Chemistry 286(25): 22688-22698. DOI: 10.1074/jbc.M110.216358.

Voss, I., Sunil, B., Scheibe, R., Raghavendra, A. S. (2013). Emerging concept for the role of photorespiration as an important part of abiotic stress response. Plant Biology (Stuttgart) 15(4, Sp. Iss. SI): 713-722. DOI: 10.1111/j.1438-8677.2012.00710.x.

Weil, E. (2004). Coral Reef Diseases in the Wider Caribbean. In Coral Health and Disease. Rosenberg E. and Loya Y., ed, Springer Berlin Heidelberg, 35-68. DOI: 10.1007/978-3662-06414-6 2.

Weil, E., Cróquer, A., Urreiztieta, I. (2009a). Temporal variability and impact of coral diseases and bleaching in La Parguera, Puerto Rico from 2003-2007. Caribbean Journal of Science 45(2-3): 221-246.

Weil, E., Cróquer, A., Urreiztieta, I. (2009b). Yellow band disease compromises the reproductive output of the Caribbean reef-building coral Montastraea faveolata (Anthozoa, Scleractinia). Diseases of Aquatic Organisms 87(1-2): 45-55. DOI: 10.3354/dao02103.

Weil, E., Ritchie, K. B., Cróquer, A., Cunning, J. R., Smith, G. W. (2008). Inoculation of Vibrio spp onto Montastraea faveolata fragments to determine potential pathogenicity. Proceedings of the 11th International Coral Reef Symposium 202-205.

Weil, E., Rogers, C. S. (2011). Coral Reef Diseases in the Atlantic-Caribbean. Dordrecht, Springer. DOI: 10.1007/978-94-007-0114-4_27.

Weis, V. M. (2008). Cellular mechanisms of Cnidarian bleaching: stress causes the collapse of symbiosis. Journal of Experimental Biology 211(19): 3059-3066. DOI: 10.1242/jeb.009597.

Wolenski, F. S., Garbati, M. R., Lubinski, T. J., Traylor-Knowles, N., Dresselhaus, E., Stefanik, D. J., Goucher, H., Finnerty, J. R., Gilmore, T. D. (2011). Characterization of the core elements of the NF-kappaB signaling pathway of the sea anemone Nematostella vectensis. Molecular and Cellular Biology 31(5): 1076-1087. DOI: 10.1128/MCB.0092710.

Wood-Charlson, E. M., Hollingsworth, L. L., Krupp, D. A., Weis, V. M. (2006). Lectin/glycan interactions play a role in recognition in a coral/dinoflagellate symbiosis. Cell Microbiology 8(12): 1985-1993. DOI: 10.1111/j.1462-5822.2006.00765.x.

Zhou, Y., Zhu, Y. Q. (2015). Diversity of bacterial manipulation of the host ubiquitin pathways. Cellular Microbiology 17(1): 26-34. DOI: 10.1111/cmi.12384. 
Table $\mathbf{1}$ (on next page)

Primers used for RDA protocol

Table 1. RDA primer sequence information. 


\begin{tabular}{|l|l|}
\hline Primer Name & Sequence \\
\hline R12 & 5'-GATCTGCGGTGA-3' \\
\hline R24 & 5'-AGCACTCTCCAGCCTCTCACCGCA-3' \\
\hline J12 & 5'-GATCTGTTCATG-3' \\
\hline J24 & 5'-ACCGACGTCGACTATCCATGAACA-3' \\
\hline N12 & 5'-GATCTTCCCTCG-3' \\
\hline N24 & 5'-AGGCAACTGTGCTATCCGAGGGAA-3' \\
\hline
\end{tabular}

1

2 Table 1. RDA primer sequence information. 


\section{Table 2 (on next page)}

RDA candidates screened CYBD analysis

Table 2. Fourteen RDA products screened for inclusion in qPCR assays. Probes 1-5 were screened as potential qPCR control genes. Probes 6-14 were screened as potentially differentially expressed transcripts. 


\begin{tabular}{|l|l|l|}
\cline { 2 - 3 } \multicolumn{1}{c|}{} & RDA Probes & Putative genes of interest \\
\hline 1. & H40D1-30 & Ribosomal s8 \\
\hline 2. & H40D1-50A & 18s rRNA gene \\
\hline 3. & H4D1-22 & Poly-A binding protein \\
\hline 4. & H3D1-20 & Ribosomal Protein \\
\hline 5. & H3D1-30 & ribosomal protein L27a \\
\hline 6. & H40D1-46 & Tetratricopeptide repeat \\
\hline 7. & H4D1-20 & Predicted PHD-finger \\
\hline 8. & H3D1-4 & Ubiquitin Ligase \\
\hline 9. & H4D1-1 & DNA J like \\
\hline 10. & H4D1-2 & Cytochrome Oxidase Subunit 1 \\
\hline 11. & H40D1-55 & superoxide dismutase-like \\
\hline 12. & H40D1-56 & skp1 family protein \\
\hline 13. & H40D1-60 & IG domain \\
\hline 14. & H40D1-64 & Early Growth Response \\
\hline
\end{tabular}

1

2 Table 2. Fourteen RDA products screened for inclusion in qPCR assays. Probes 1-5 were 3 screened as potential qPCR control genes. Probes 6-14 were screened as potentially

4 differentially expressed transcripts. 


\section{Table 3 (on next page)}

\section{Primers for GOls}

Table 3. Genes of Interest and their corresponding primers used in qPCR reactions. 


\begin{tabular}{lllcc}
$\begin{array}{l}\text { RDA } \\
\text { Probe ID }\end{array}$ & $\begin{array}{l}\text { Putative } \\
\text { Gene Homolog }\end{array}$ & Primers & $\begin{array}{c}\text { Amplicon } \\
\text { Length } \\
\text { (bases) }\end{array}$ & $\begin{array}{c}\text { Annealing } \\
\text { Temp }\end{array}$ \\
\hline H40D1-64 & Early Growth Response & $\begin{array}{l}\text { F: TGAACAGATTTGCGACGTTT } \\
\text { R: AGCCCCAACTGTCTCTCTT }\end{array}$ & 154 & $56^{\circ} \mathrm{C}$ \\
H4D1-22 & Poly-A binding protein & $\begin{array}{l}\text { F: TCGGTGTCAAAATGGACAAA } \\
\text { R: ATCCTTCCCTTCGCAAATCT }\end{array}$ & 178 & $\begin{array}{c}54^{\circ} \mathrm{C} \text { or } \\
56^{\circ} \mathrm{C}\end{array}$ \\
H4D1-2 & Cytochrome Oxidase & $\begin{array}{l}\text { F: TGGAAAGGATGGGATTCTTC } \\
\text { R: TGAATGGAGAAAAGATTGTTGC }\end{array}$ & 164 & $56^{\circ} \mathrm{C}$ \\
H3D1-4 & Ubiquitin Ligase & $\begin{array}{l}\text { F: GGCATTTTAACGGGGTCTTT } \\
\text { R: GTTGGGTGATGAGACGGACT }\end{array}$ & 165 & $54^{\circ} \mathrm{C}$ \\
H40D1-55 & Superoxide Dismutase & $\begin{array}{l}\text { F: CAGGAACTGGAACCGATGAT } \\
\text { R: TTACCGACGTCGACTATCCA }\end{array}$ & 168 & $56^{\circ} \mathrm{C}$ \\
Table 3. Genes of Interest and their & corresponding primers used in qPCR reactions.
\end{tabular}




\section{Table 4 (on next page)}

RDA BLAST results

Table 4. BLAST results for RDA probes. Searches were performed using BLASTX at NCBI using the non-redundant database $(\mathrm{nr})$ with default search parameters. 


\begin{tabular}{|l|l|c|l|l|l|}
\hline RDA Probe & Accession & E-value & Putative Homolog & Organism ID & $\begin{array}{l}\text { Homolog } \\
\text { Accession \# }\end{array}$ \\
\hline H4D1-22 & JZ875039 & $2 \mathrm{e}^{-54}$ & Poly-A binding protein & Nematostella vectensis & XP_001625306 \\
\hline H40D1-64 & JZ875040 & $1 \mathrm{e}^{-14}$ & Early Growth Response & Echinococcus granulosus & EUB53836 \\
\hline H4D1-2 & KT149212 & $6 \mathrm{e}^{-49}$ & Cytochrome Oxidase & $\begin{array}{l}\text { Symbiodinium } \\
\text { microadriaticum }\end{array}$ & ABK57976.1 \\
\hline H3D1-4 & JZ875037 & $2 \mathrm{e}^{-14}$ & Ubiquitin Ligase & Rattus norvegicus & XP_221191.5 \\
\hline H40D1-55 & JZ875038 & $1 \mathrm{e}^{-10}$ & Superoxide dismustase-like & Saccoglossus kowalevskii & XP_002734284 \\
\hline
\end{tabular}

1

2 Table 4. BLAST results for RDA probes. Searches were performed using BLASTX at NCBI 3 using the non-redundant database (nr) with default search parameters. 


\section{Figure 1 (on next page)}

Photographs of CYBD infected colonies

Figure 1: Representative photographs of CYBD infected colonies. (A) Several focal areas of initial stages of Caribbean Yellow Band Disease (CYBD in a large colony of Orbicella faveolata in La Parguera. (B) A large wide initial lesion of CYBD in $O$. faveolata with marks showing the sampled areas (red dot identifies the transition area and blue dot the CYBD active lesion), and (C) Another large colony with advanced stages of the disease. (photopraphs E.Weil). 

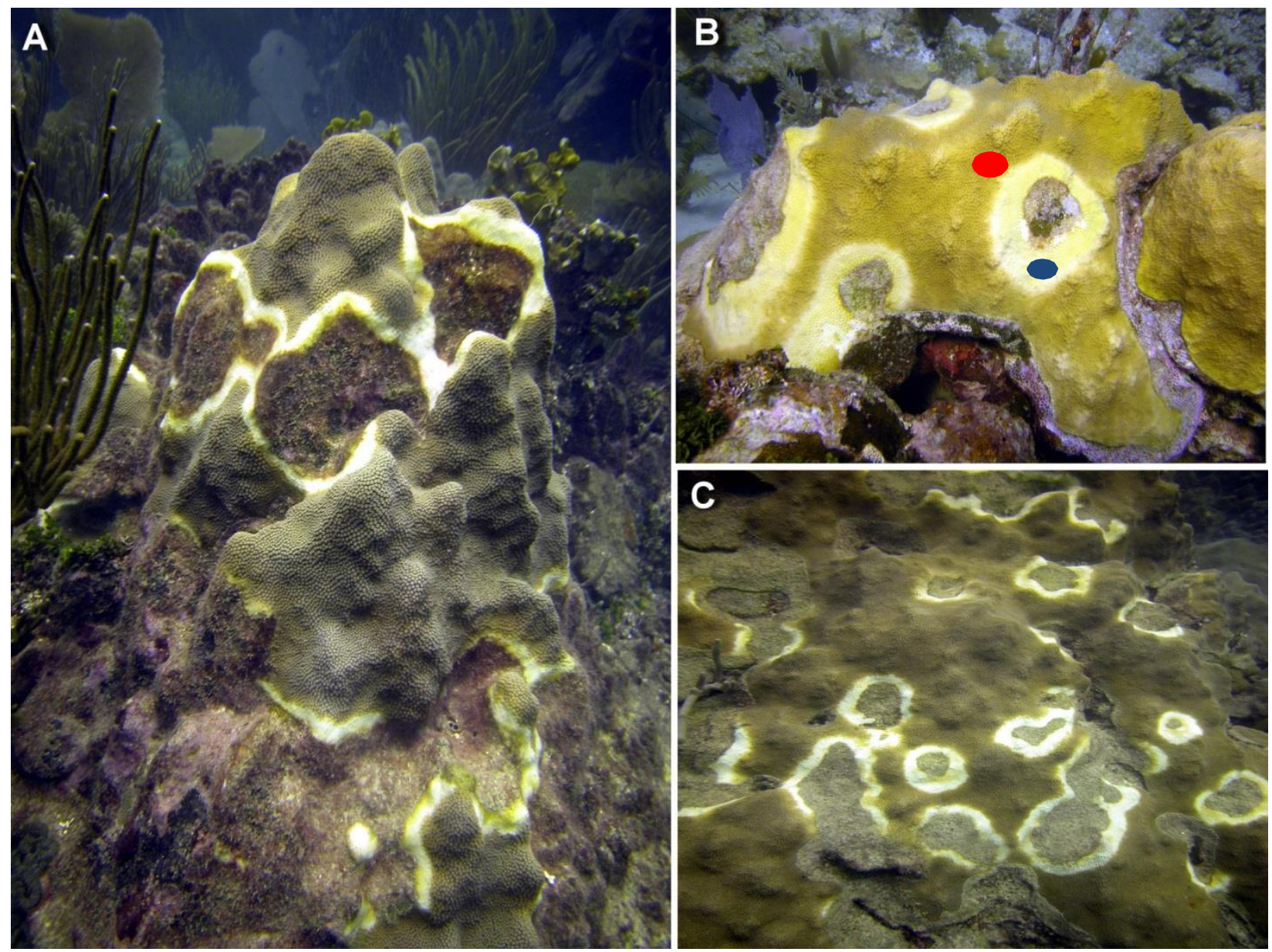

Figure 1: Representative photographs of CYBD infected colonies. (A) Several focal areas of initial stages of Caribbean Yellow Band Disease (CYBD in a large colony of Orbicella faveolata in La Parguera. (B) A large wide initial lesion of CYBD in O. faveolata with marks showing the sampled areas (red dot identifies the transition area and blue dot the CYBD active lesion), and (C) Another large colony with advanced stages of the disease. (photographs E.Weil). 


\section{Figure 2 (on next page)}

\section{Cytochrome oxidase expression}

Figure 2. Expression of zooxanthellae Cytochrome Oxidase. The $\Delta \Delta C q$ values represent transformed expression of cytochrome oxidase relative to PABP expression. An * represents a condition that was significantly different in expression $(\mathrm{P}<0.01)$ relative to other conditions. Error bars represent $\pm \mathrm{SE}$. 


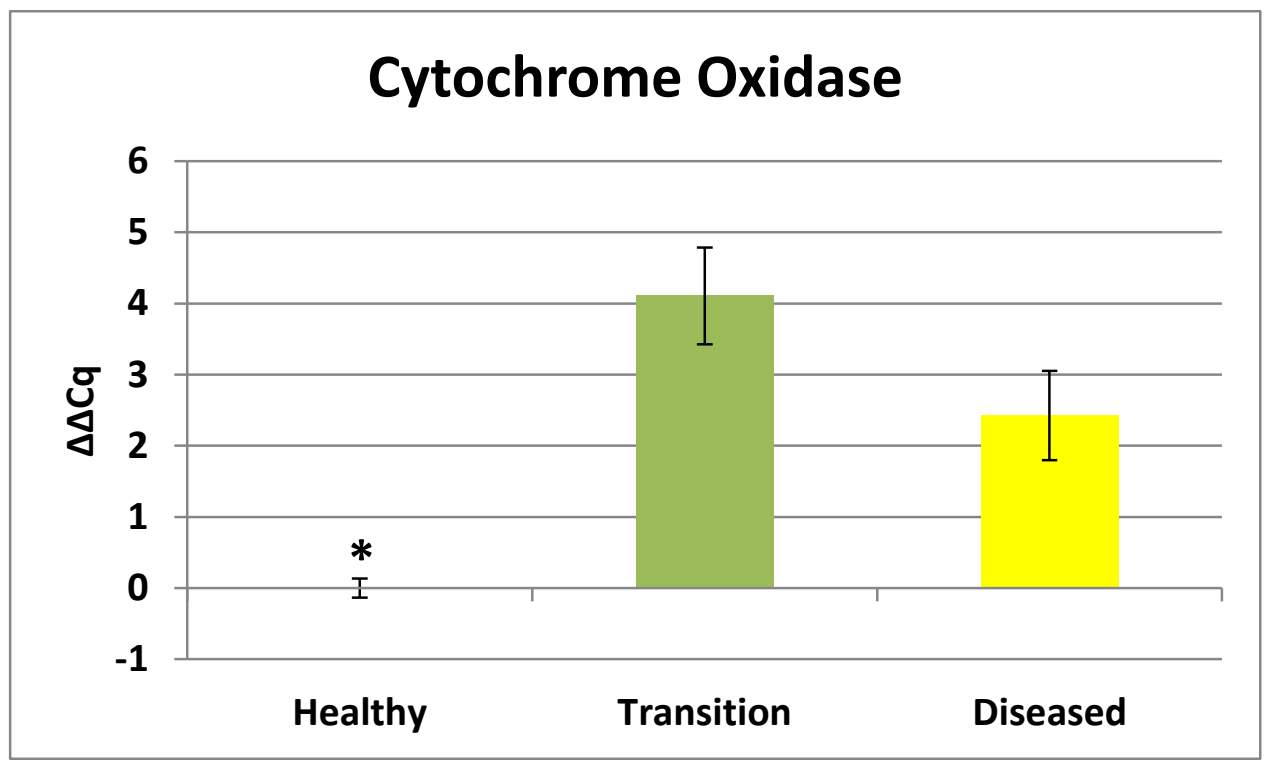

Figure 2. Expression of zooxanthellae Cytochrome Oxidase. The $\Delta \Delta \mathrm{Cq}$ values represent transformed expression of cytochrome oxidase relative to PABP expression. An * represents a condition that was significantly different in expression $(\mathrm{P}<0.01)$ relative to other conditions. Error bars represent \pm SE. 
Figure 3 (on next page)

Early Growth Response expression

Figure 3. Expression of early growth response (EGR). The $\Delta \Delta C q$ values represent transformed expression of the EGR relative to PABP expression. An * represents a condition that was significantly different in expression $(P<0.01)$ relative to other conditions. Error bars represent $\pm \mathrm{SE}$. 


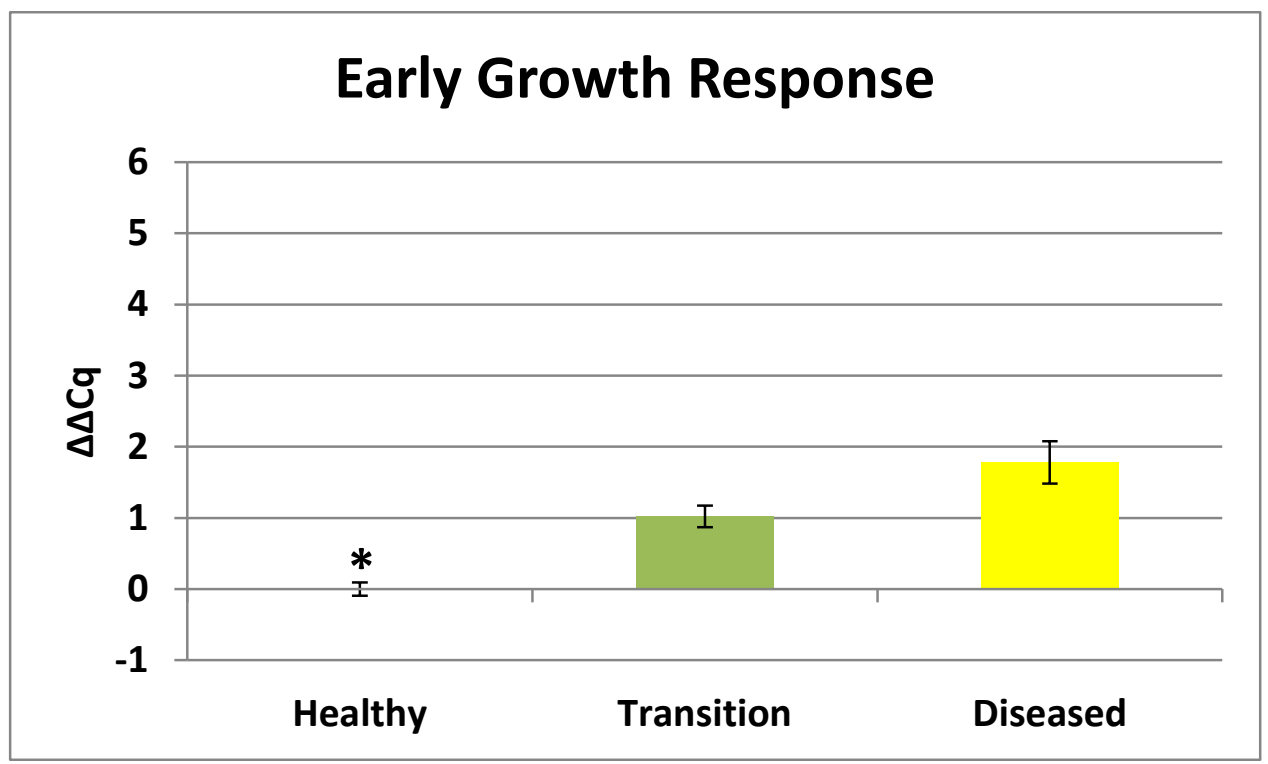

Figure 3. Expression of early growth response (EGR). The $\Delta \Delta \mathrm{Cq}$ values represent transformed expression of the EGR relative to PABP expression. An * represents a condition that was significantly different in expression $(\mathrm{P}<0.01)$ relative to other conditions. Error bars represent \pm SE. 


\section{Figure 4 (on next page)}

\section{Ubiquitin Ligase expression}

Figure 4. Expression of Ubiquitin Ligase. The $\Delta \Delta C q$ values represent transformed expression of ubiquitin ligase relative to PABP expression. An * represents a condition that was significantly different in expression $(\mathrm{P}<0.01)$ relative to other conditions. Error bars represent $\pm \mathrm{SE}$. 


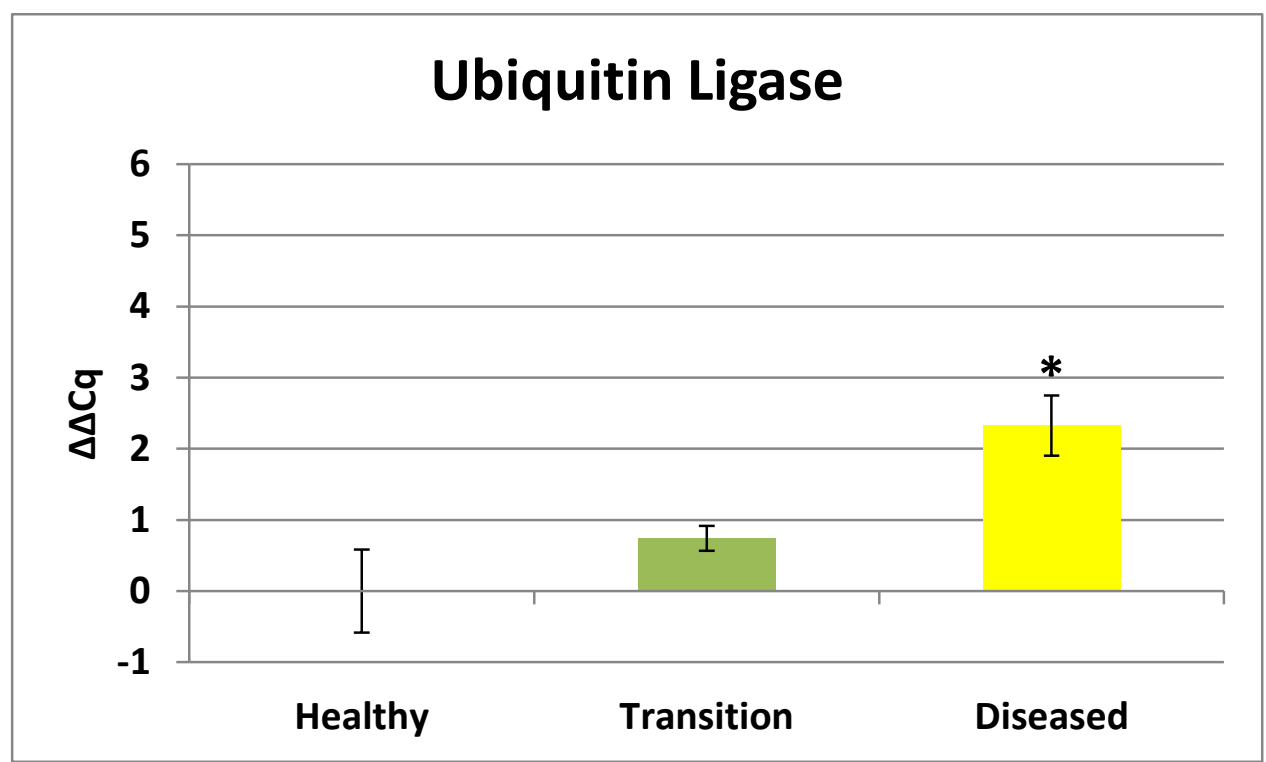

Figure 4. Expression of Ubiquitin Ligase. The $\Delta \Delta \mathrm{Cq}$ values represent transformed expression of ubiquitin ligase relative to $\mathrm{PABP}$ expression. An * represents a condition that was significantly different in expression $(\mathrm{P}<0.01)$ relative to other conditions. Error bars represent \pm SE. 